\title{
Lime and gypsum to improve root depth of orange crop in an Ultisol of the Coastal Tablelands
}

\author{
Lafayette F. Sobral ${ }^{1}$, Fernando L. D. Cintra ${ }^{1} \&$ Jot T. Smyth ${ }^{2}$
}

\begin{abstract}
Coastal Tableland is a landscape unit in the N orth East of Brazil in which the main soils are Ultisols. In these soils, a compacted layer denominated "cohesive horizon" occurs and root growth is limited by it. An experiment with five treatments and six replications was set up in order to study how liming and gypsum could improve root depth of orange (Citrus sinensis L. O sbeck) crop in an Ultisol in which a compacted layer was found at $0.3 \mathrm{~m}$. Treatments were: $A$ - No liming and no gypsum; B - Liming to achieve $60 \%$ base saturation; C - B 1 t of gypsum ha-1 ; D - B + 2 t of gypsum ha-1 and E - B +3 t of gypsum ha-1. Gypsum increased calcium and sulfate in the cohesive horizon. Surface application of lime and gypsum did not cause changes in soil density and total porosity in the cohesive horizon. An improvement of root length was observed at the cohesive horizon.
\end{abstract}

Key words: compacted layer, cohesive horizon, root growth

\section{Calcário e gesso no aprofundamento radicular da laranjeira em um Argissolo dos Tabuleiros Costeiros}

RESUMO

Os tabuleiros costeiros são uma unidade de paisagem em que um dos principais solos são os Argissolos, nos quais, uma camada compactada, denominada "horizonte coeso" ocorre e o crescimento radicular é por ela limitado. Um experimento com cinco tratamentos e seis repetições foi implantado para se estudar os efeitos da calagem e do gesso no aprofundamento radicular da laranjeira (Citrus sinensis L. O sbeck) em um Argissolo onde o horizonte coeso está a 0,3 m de profundidade. Os tratamentos foram: A - Sem gesso e sem calagem; B - Calagem para atingir $60 \%$ de saturação por bases; $C$ - B +1 tha-1 de gesso ; $D$ - B + 2 tha $^{-1}$ de gesso; e $E-B+3$ t ha-1 de gesso. A calagem e 0 gesso aumentaram significativamente os teores de sulfato e de calcio no solo até a profundidade de $0,40 \mathrm{~m}$. A aplicação a lanço de calcário e gesso não causaram modificações na densidade do solo e na porosidade total da camada compactada "horizonte coeso". Foi observado um aumento do comprimento das raízes da laranjeira na camada compactada.

Palavras-chave: camada compactada, horizonte coeso, crescimento radicular

\footnotetext{
${ }^{1}$ Embrapa Tabuleiros Costeiros, Avenida Beira Mar 3250, CEP 49025-040, Aracaju, SE. Fone:(79) 40091371. E-mail: Iafayete@cpatc.embrapa.br; cintra@cpatc.embrapa.br

${ }^{2}$ Soil Science Department, North Carolina State University, Raleigh NC 27695-7619 E- mail: jot_smyth@ncsu.edu
} 


\section{INTRODUCTION}

Coastal tablelands is a landscape unit in Brazil where one of the main soils are Ultisols. They come from a tertiary geological material and are well weathered. In these soils, a compacted layer, denominated cohesive horizon, occurs at different depths and root growth is limited by it. The decrease in root density in the cohesive horizon is due to an increase in soil density and a decrease in total porosity (Santana et al., 2006; Souza et al., 2007). Superficial root systems increase plant stress under water deficit, decrease yield and longevity of oranges trees in this soil.

Cintra et al. (1999), working in a coastal tablelands Ultisol, found that $90 \%$ of citrus rootstocks roots were concentrated down to $0.4 \mathrm{~m}$ and that $61 \%$ of them were only down to $0.2 \mathrm{~m}$. A significant root length reduction from $380 \mathrm{~cm}$ to $50 \mathrm{~cm}$ per $0.1 \mathrm{~m}$ 2 was observed at $0.3 \mathrm{~m}$ soil depth. A compacted layer should have caused that reduction, due to an increase in soil bulk density and mechanical impedance, decreasing soil aeration.

Radcliffe et al. (1986) reported that gypsum led to a decrease in the cone index in cropped plots which was accompanied by an increase in aggregate stability and hydraulic conductivity. In order to verify if it was a direct gypsum effect, measurements of the cone index were made in fallow plots, where gypsum had been applied. The cone index was equal or higher in these plots, indicating that soil physical improvements were caused by increasing root activity, due to gypsum application.

Chemical constraints, such as low calcium and high aluminum down in the soil profile, also have been reported as a cause of superficial root systems. Caires et al. (2006) observed that root density correlated positively with exchangeable calcium. Sumner (1992), proposed four mechanisms to explain root depth by increasing calcium and decreasing aluminum in the soil underneath horizons: a) self liming by exchange of $\mathrm{OH}^{-}$by $\mathrm{SO}_{4}^{-2}$ followed by hydrolysis and precipitation of the exchangeable aluminum; b) precipitation of the basic aluminum sulphate; c) co-adsorption of $\mathrm{SO}_{4}^{-}$ 2 and $\mathrm{Al}^{+3}$ by increasing oxides negative superficial charges and d) formation of ionic pairs such as $\mathrm{AlSO}_{4}$, which is less toxic than the exchangeable aluminum.

Surface incorporation of lime has little effect in the subsoil amelioration, and mechanical procedures of profiles modification require special equipment not always available (Farina et al., 2000). Calcium sulfate has been proposed to overcome chemical and physical constraints in sub superficial horizons (Sumner, 1992). Ritchey et al. (1980) compared the rate of descent of $\mathrm{Ca}$ from $\mathrm{CaSO}_{4}, \mathrm{CaCl}_{2}$ and $\mathrm{CaCO}_{3}$. Calcium chloride had the highest, $\mathrm{CaSO}_{4}$ intermediate and $\mathrm{CaCO}_{3}$ the lowest. Calcium chloride is the most soluble, but the anion chloride is the least reactive with the soil. Calcium sulfate is less soluble and $\mathrm{SO}_{4}$ can be adsorbed to a greater extent than chloride. Calcium carbonate is the least soluble but the accompanying anion $\mathrm{CO}_{3}$ reacts with soil acidity and the electro neutrality cannot be maintained. In addition, $\mathrm{CaCO}_{3}$ can generate exchange capacity, which would prevent calcium from leaching. Identical results regarding $\mathrm{CaSO}_{4}$, and $\mathrm{CaCO}_{3}$ were found by Liu \& Hue (2001).
The objective of this work was to study the effect of lime and gypsum in improving orange tree root depth in a coastal tablelands Ultisol with a compacted layer denominated cohesive horizon.

\section{MATERIAL AND METHODS}

In order to study the effects of lime and lime plus gypsum in the overcoming of a compacted layer denominated cohesive horizon by orange tree roots, an experiment was established in an Ultisol of the coastal tablelands where an increase in soil density and a decrease in total porosity are found at $0.3 \mathrm{~m}$. Four-year-old orange (Citrus sinensis L. Osbeck) crop planted in a $6 \times 4 \mathrm{~m}$ spacing were used. In the first year the treatments were: a) No liming and no gypsum (control); b) Liming to achieve $60 \%$ bases saturation; c) B + gypsum as $10 \%$ of the lime dose; d) B + gypsum as $20 \%$ of the lime dose and e) B + gypsum as $30 \%$ of the lime dose. A soil sample was collected from the compacted layer at $0.3 \mathrm{~m}$ before the treatments. Calcium and magnesium contents were $12.3 \mathrm{mmol}_{\mathrm{c}}$ $\mathrm{dm}^{-3}$, potassium $1.06 \mathrm{mmol}_{\mathrm{c}} \mathrm{dm}^{-3}$ and sodium $0.66 \mathrm{mmol}_{\mathrm{c}} \mathrm{dm}^{-3}$. Cation exchange capacity was $55.98 \mathrm{mmol}_{\mathrm{c}} \mathrm{dm}^{-3}$ and base saturation $47.01 \%$. The amount of lime was calculated based on the basis saturation method and it was $1000 \mathrm{~kg} \mathrm{ha}^{-1}$. Doses of gypsum were 100, 200 and $300 \mathrm{~kg} \mathrm{ha}^{-1}$. Calcium and magnesium oxides in the lime was 29.40 and $18.97 \%$ respectively, and the total neutralization power of it was $91.7 \%$, which takes into account the fineness of the liming material. The treatments were applied on 04/17/97.

Soil samples collected on 05/12/1998, after one rainfall season, showed that the amount of gypsum applied in treatment D (200 kg ha $\left.{ }^{-1}\right)$ was not enough to provide a sufficient descent of calcium (Table 1). The amount of gypsum was increased to 1,2 and $3 \mathrm{t} \mathrm{ha}^{-1}$ for treatments $\mathrm{c}, \mathrm{d}$ and e respectively, which was applied on 08/06/1998.

Table 1. Calcium content in soil samples collected

\begin{tabular}{cccc}
\hline Soil depth & $\begin{array}{c}\text { Control (a) } \\
\left(\mathbf{m m o l}_{\mathbf{c}} \mathbf{~ m}^{-3}\right)\end{array}$ & $\begin{array}{c}\text { Lime (b) } \\
\left(\mathbf{m m o l}_{\mathbf{c}} \mathbf{d m}^{-3}\right)\end{array}$ & $\begin{array}{c}\text { Lime+ 200 kg ha. } \\
\text { gypsum (d) }\end{array}$ \\
$00-10 \mathrm{~cm}$ & $9.85 \mathrm{Ba}$ & $13.16 \mathrm{Aa}$ & $12.03 \mathrm{ABa}$ \\
$10-20 \mathrm{~cm}$ & $7.66 \mathrm{Ab}$ & $8.05 \mathrm{Ab}$ & $8.22 \mathrm{Ab}$ \\
$20-30 \mathrm{~cm}$ & $7.33 \mathrm{Ab}$ & $8.22 \mathrm{Ab}$ & $6.59 \mathrm{Ab}$ \\
$30-40 \mathrm{~cm}$ & $7.76 \mathrm{Ab}$ & $8.33 \mathrm{Ab}$ & $6.57 \mathrm{Ab}$ \\
\hline
\end{tabular}

Means followed by different letters present significant differences by Duncan test $(\mathrm{P}<0,05)$; Capital letters compare treatments and regular ones compare depth.

Soil $\mathrm{pH}$ was measured in water using a 2:1 relationship. Calcium and $\mathrm{Al}$ were obtained by extraction with $\mathrm{KCl} 1 \mathrm{~N}$. Calcium was determined by atomic absorption and $\mathrm{Al}$ by titration with $\mathrm{NaOH}$ to the phenolphthalein end point. Soil sulfate was extracted by calcium monophosphate precipitated as $\mathrm{BaCl}_{2}$ and determined by turbidimetry. Soil density and total porosity were accomplished according to Silva (1999). Root measurements were made opening trenches five meters long and one meter deep at the east and west sides of the 
plant, distanced $50 \mathrm{~cm}$ from its trunk. Roots were exposed by scratching the profile walls and painted white. Trenches were covered and roots filmed with artificial light. The software SIARCS was used to analyze root images and root length was calculated and expressed as cm of roots for each $0.02 \mathrm{~m}^{-2}$ of trench wall (Crestana et al., 1994).

\section{RESULTS AND DISCUSSION}

Gypsum significantly increased sulfate and calcium contents down to $0.4 \mathrm{~m}$ (Figure 1A) and did not cause any change

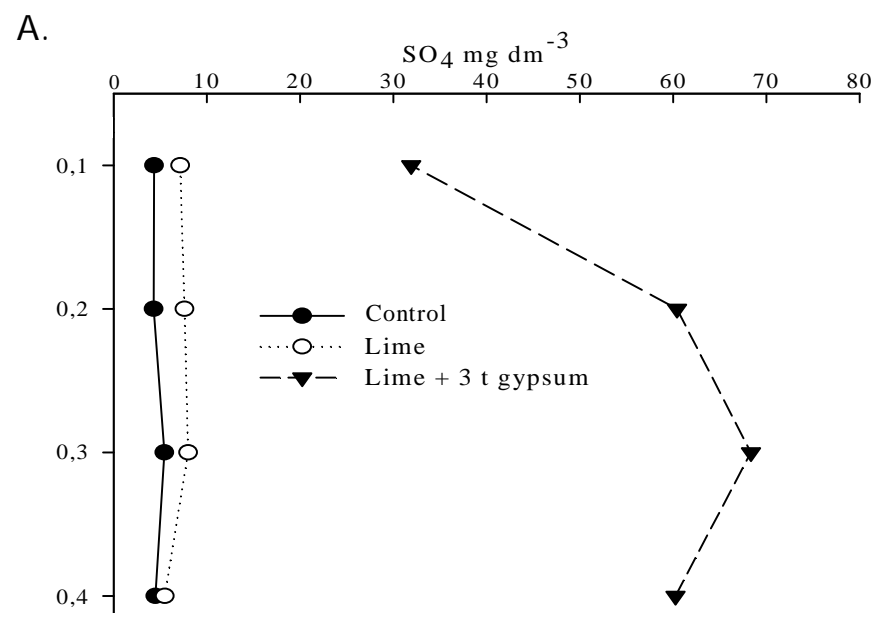

B.

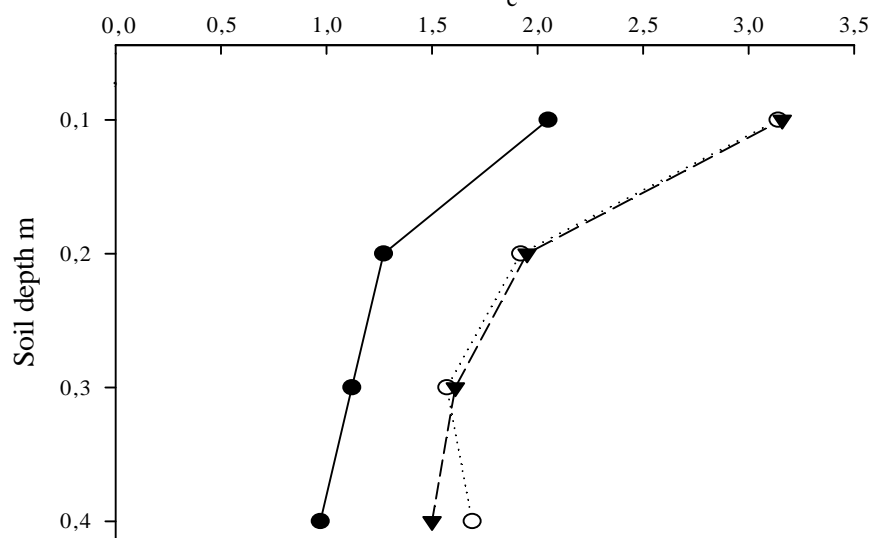

C.
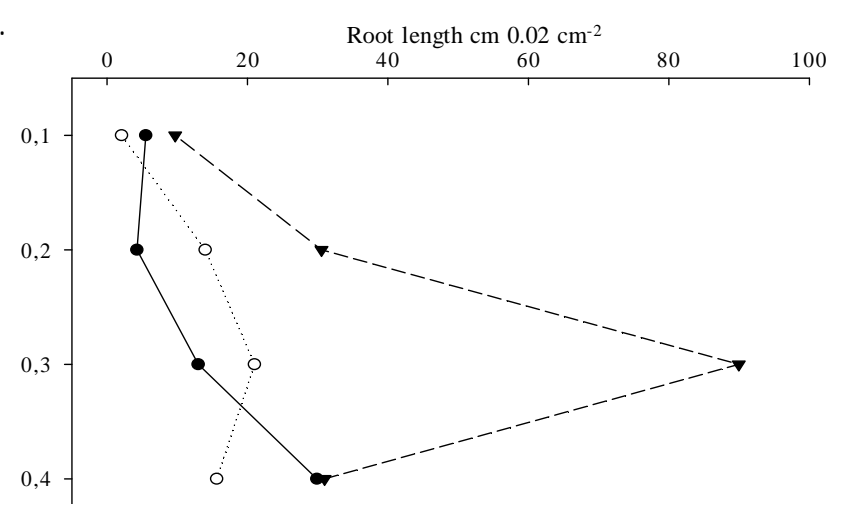

Figure 1. Descent of sulfate (A), and calcium (B) in the control, lime and lime plus 3 tha-1 gypsum treatments and root length $(C)$ as influenced by lime and lime plus 3 t ha $^{-1}$ of gypsum on the soil $\mathrm{pH}$. Calcium sulfate dissociates into $\mathrm{Ca}^{2+}$ and $\mathrm{SO}_{4}{ }^{2-}$ but also forms a ionic pair $\mathrm{CaSO}_{4}{ }^{0}$ (Ritchey et al., 1980). This mechanism allows the calcium sulfate to percolate in the soil profile with water. Lime also increased calcium and $\mathrm{pH}$ down to $0.4 \mathrm{~m}$ depth (Figure 1B) (Table 2). Low soil clay content and the predominance of kaolinite probably caused calcium from the lime to go down to $0.4 \mathrm{~m}$, since the soil lacks enough negative charges to hold calcium from $\mathrm{CaCO}_{3}$. In addition, acidity was not high enough to prevent carbonate to go down with calcium, neither were the extra negative charges created by carbonate (Ritchey et al., 1980).

An increase in root length was observed at $0.3 \mathrm{~m}$ (Figure 1C). Caires et al. (2006) observed that root density correlated positively with exchangeable calcium. According to Marschner (1995), a exogenous calcium supply is necessary for root extension and, in the absence of the nutrient, cell extension is inhibited.

Table 2. Soil density, total porosity, pH and aluminum after lime and gypsum application

\begin{tabular}{|c|c|c|c|c|}
\hline Treatment & $\begin{array}{l}\text { Soil density } \\
\left(\mathrm{g} \mathrm{cm}^{-3}\right)\end{array}$ & Total porosity & $\mathrm{pH}$ & $\begin{array}{c}\mathrm{Al}^{3+} \\
\left(\mathrm{cmol}_{\mathrm{c}} \mathrm{dm}^{-3}\right)\end{array}$ \\
\hline \multicolumn{5}{|c|}{$0.1 \mathrm{~m}$} \\
\hline Control & $1.72 \mathrm{a}$ & $29.15 \mathrm{a}$ & $4.90 \mathrm{~b}$ & $0.18 \mathrm{a}$ \\
\hline Lime & $1.68 \mathrm{a}$ & $33.66 \mathrm{a}$ & $5.51 \mathrm{a}$ & $0.03 \mathrm{~b}$ \\
\hline Lime +1 tG & $1.71 \mathrm{a}$ & $31.08 \mathrm{a}$ & $5.35 a$ & $0.04 \mathrm{~b}$ \\
\hline Lime +2 tG & $1.68 \mathrm{a}$ & $32.54 \mathrm{a}$ & $5.46 \mathrm{a}$ & $0.03 \mathrm{~b}$ \\
\hline Lime +3 tG & $1.66 \mathrm{a}$ & $33.40 \mathrm{a}$ & $5.42 \mathrm{a}$ & $0.04 \mathrm{~b}$ \\
\hline \multicolumn{5}{|c|}{$0.2 \mathrm{~m}$} \\
\hline Control & $1.77 \mathrm{a}$ & $28.14 \mathrm{a}$ & $4.68 \mathrm{~b}$ & $0.20 a$ \\
\hline Lime & $1.77 \mathrm{a}$ & $29.49 a$ & $5.10 \mathrm{a}$ & $0.21 a$ \\
\hline Lime +1 tG & $1.74 \mathrm{a}$ & $31.34 \mathrm{a}$ & $4.80 \mathrm{ab}$ & $0.32 \mathrm{a}$ \\
\hline Lime +2 tG & $1.69 \mathrm{a}$ & $32.41 \mathrm{a}$ & $4.92 a b$ & $0.21 a$ \\
\hline Lime +3 tG & $1.66 \mathrm{a}$ & $33.35 \mathrm{a}$ & $4.75 \mathrm{ab}$ & $0.23 a$ \\
\hline \multicolumn{5}{|c|}{$0.3 \mathrm{~m}$} \\
\hline Control & $1.80 a b$ & $27.45 a$ & $4.50 \mathrm{~b}$ & $0.22 b$ \\
\hline Lime & $1.83 \mathrm{a}$ & $27.63 a$ & $4.82 \mathrm{a}$ & $0.21 \mathrm{~b}$ \\
\hline Lime +1 tG & $1.77 \mathrm{ab}$ & $30.13 a$ & $4.38 \mathrm{~b}$ & $0.55 a$ \\
\hline Lime +2 tG & $1.73 a b$ & $29.87 \mathrm{a}$ & $4.60 a b$ & $0.22 b$ \\
\hline Lime +3 tG & $1.66 \mathrm{~b}$ & $33.75 \mathrm{a}$ & $4.42 \mathrm{~b}$ & $0.27 \mathrm{~b}$ \\
\hline \multicolumn{5}{|c|}{$0.4 \mathrm{~m}$} \\
\hline Control & $1.73 \mathrm{a}$ & $29.62 \mathrm{a}$ & $4.45 b$ & $0.26 \mathrm{a}$ \\
\hline Lime & $1.83 \mathrm{a}$ & $27.03 \mathrm{a}$ & $4.80 \mathrm{a}$ & $0.16 \mathrm{~b}$ \\
\hline Lime +1 tG & $1.81 \mathrm{a}$ & $28.91 \mathrm{a}$ & $4.42 \mathrm{~b}$ & $0.33 a$ \\
\hline Lime +2 tG & $1.71 \mathrm{a}$ & $31.31 \mathrm{a}$ & $4.63 \mathrm{ab}$ & $0.24 a b$ \\
\hline Lime +3 tG & $1.72 \mathrm{a}$ & $31.16 \mathrm{a}$ & $4.35 \mathrm{~b}$ & $0.30 \mathrm{a}$ \\
\hline
\end{tabular}

Lime and lime plus gypsum did not affect soil density and soil total porosity at 0.1 and $0.2 \mathrm{~m}$ (Table 2). Sumner et al. (1990) observed the ability of surface applied gypsum to increase hardpans susceptibility to rooting. Probably, gypsum triggers some chain events, initiated by clay flocculation, leading to rooting improvement and consequent aggregation, probably by particles binding by the roots. Radcliffe et al. (1986) reported a decrease in the cone index which was accompanied by an increase of root activity due to gypsum application. Santana et al. (2006) observed a decrease in root density at the cohesive horizon which was related to an increase in soil density and a decrease in soil total porosity. 
Souza et al. (2008) observed that of orange crop root depth was higher in low fertility soils without a cohesive horizon than in higher fertility soils with a cohesive horizon, suggesting that physical constraints, such the cohesive horizon, overcome the chemical ones in preventing orange tree root depth. In this study there was no significant effect of lime and lime plus gypsum on soil density and total porosity, however, a trend was observed indicating that the physical improvement at the cohesive horizon, should have an important role in increasing orange tree root depth.

The effect of lime on decreasing Al was observed only at $0.1 \mathrm{~m}$, and lime plus gypsum did not decrease $\mathrm{Al}$ down in the soil profile. In the same soil Anjos (1997) also observed that the effect of lime was more pronounced at $0.1 \mathrm{~m}$.

\section{CONCLUSIONS}

1. Gypsum increased calcium and sulfate at the compacted layer cohesive horizon.

2. Surface application of lime and gypsum was not able to promote changes in soil density and total porosity at the compacted layer cohesive horizon.

3. An increase on root length was observed at the compacted layer cohesive horizon.

\section{LITERATURE CITED}

Anjos, J. L. dos. Calagem pelo método de saturação por bases em um solo Podzólico Amarelo dos tabuleiros costeiros de Sergipe cultivado com Citros. Recife: UFRPE, 1997. 83p. Dissertação Mestrado

Caíres, E. F.; Corrêa, J. C. L.; Churka, S.; Barth, G.; Garbuio, F. G. Surface application of lime ameliorates subsoil acidity and improves root growth and yield of wheat in an acid soil under no-till system. Scientia Agricola, v.63, p.502-509, 2006.

Cintra, F. L. D.; Libardi, P. L.; Jorge, L. A. C. Distribuição do sistema radicular de porta-enxerto de citros em ecossistema de tabuleiro costeiro. Revista Brasileira de Fruticultura, v.21, p.313-317,1999.
Crestana, S.; Guimaraes, M. F.; Jorge, L. A. C.; Ralish, R.; Tozzi, C. L.; Torre, A.; Vaz, C. M. P. Avaliação da distribuicao de raízes no solo auxiliada por processamento de imagens digitais. Revista Brasileira de Ciência do Solo, v.18, p.365-371, 1994.

Farina, M. P. W.; Channon P.; Thibaud, G. R. A comparison of strategies for ameliorating subsoil acidity: II. Long-term soil effects. Soil Science Society America Journal, v.64, p.652-658, 2000.

Liu, J.; Hue, N. V. Amending subsoil acidity by surface application of gypsum, lime and composts. Communications in Soil Science and Plant Analysis, v.32, p.2117-2132, 2001.

Marschner, H. Mineral nutrition of higher plants. London: Academic Press, 1995. 889p.

Radcliffe, D. E.; Clark, R. L.; Sumner, M. E. Effect of gypsum and deep-rooting perennials on subsoil mechanical impedance. Soil Science Society America Journal, v.50, p.1566-1570, 1986.

Ritchey, K. D.; Sousa, D. M. G.; Lobato, E.; Correa, O. Calcium leaching to increase rooting depth in a Brazilian savannah soil. Agronomy Journal, v.72, p.40-46, 1980.

Santana, M. B.; Souza, L. da S.; Souza, L. D.; Fontes, L. E. F. Atributos físicos do solo e distribuição do sistema radicular de citros como indicadores de horizontes coesos em dois solos de tabuleiros costeiros do Estado da Bahia. Revista Brasileira de Ciência do Solo, v.30, p.1-12, 2006.

Silva, F. C. da. (org). Manual de análises químicas de solos, plantas e fertilizantes. Brasília: Embrapa Comunicação para Transferência de Tecnologia, 1999. 370p.

Souza, L. D.; Souza, L. da S.; Ledo, C. A. da S. Sistema radicular dos citros em Neossolo Quartzarênico dos tabuleiros costeiros sob irrigação e sequeiro. Pesquisa Agropecuária Brasileira, v.42, p.1373-1381, 2007.

Souza, L. da S.; Souza, L. D; Paiva, A. de Q.; Rodrigues, A. C. V.; Ribeiro, L. da S. Distribuição do sistema radicular de citros em uma toposequencia de solos de tabuleiro costeiro do Estado da Bahia. Revista Brasileira de Ciencia de Solo, v.32, p.503-513, 2008.

Sumner, E. M. Uso atual do gesso no mundo em solos acidos. In: Seminario Sobre o Uso de Gesso na Agricultura, 2, 1992, Uberaba. Proceedings...Uberaba: Instituto Brasileiro do Fosfato, 1992. p.7-40.

Sumner, M. E.; Radcliffe, D. E.; McCray, M.; Carter, E.; Clark, R. L. Gypsum as an ameliorant for subsoil hardpans. Soil Technology, v.3, p.253-258, 1990. 